\title{
Glycogen Storage Disease Type II
}

National Cancer Institute

\section{Source}

National Cancer Institute. Glycogen Storage Disease Type II. NCI Thesaurus. Code C84734.

An autosomal recessive inherited type of glycogen storage disease caused by deficiency of the enzyme acid alpha-glucosidase. It results in the abnormal accumulation of glycogen in the heart, skeletal muscles, liver, and nervous system. 